\title{
Emergence and growth of maize submitted to inoculant doses associated with saline water irrigation ${ }^{1}$
}

\author{
Hallyson Oliveira ${ }^{2}$, Ronaldo do Nascimento ${ }^{2}$, \\ Elka Costa Santos Nascimento ${ }^{2}$, Robson Felipe de Lima², Carlos Vailan de Castro Bezerra ${ }^{2}$
}

\begin{abstract}
Salinity, in general, affects the plant growth and development, making it a limiting problem for the agricultural production. This study aimed to evaluate the effect of inoculant doses of Azospirillum brasilense on the emergence and growth of maize submitted to salinity concentrations of the irrigation water. The experiment was carried out in a greenhouse, with a randomized blocks design, in a 3 x 5 factorial [A. brasilense doses $(0.0,0.32$ and $0.48 \mathrm{~mL} / 100$ seeds $)$ and levels of electrical conductivity of the water $\left(0.3,0.6,1.1,1.7\right.$ and $\left.\left.2.3 \mathrm{dS} \mathrm{m}^{-1}\right)\right]$, in 4 blocks, totaling 60 experimental units. The emergence percentage, emergence speed index, plant height, stem diameter, number of leaves, leaf area, leaf dry mass, stem dry mass, tassel dry mass and root dry mass were evaluated. The treatments between salinity and inoculation had no effect on seedling emergence. The salinity significantly affected growth; however, the number of leaves increased in $12.8 \%$ (V8) and $18.8 \%$ (V10), when comparing the difference between the lowest and highest studied salinity. As for the plant height, there was an increase of $3.7 \%$ up to the threshold salinity of the crop $\left(1.1 \mathrm{dS} \mathrm{m}^{-1}\right)$. There was an increase in the root dry mass with the application of inoculant doses at each studied salt level.
\end{abstract}

KEYWORDS: Zea mays L., Azospirillum brasilense, water quality.

\section{INTRODUCTION}

Maize (Zea mays L.) is one of the main grain crops produced in Brazil, especially in the rainy periods, due to its use in family faming, which, in several cases, use this crop for family consumption. As that crop originates from a tropical climate, throughout its vegetative cycle, it requires heat and water. In line with these factors, it also needs ecophysiological requirements, because the processes

\section{RESUMO}

Emergência e crescimento de milho submetido a doses de inoculante associadas a irrigação com água salina

A salinidade, em geral, afeta o crescimento e desenvolvimento das plantas, tornando-se uma problemática limitante à produção agrícola. Objetivou-se avaliar o efeito de doses de inoculante de Azospirillum brasilense na emergência e crescimento de milho submetido a concentrações de salinidade da água de irrigação. O experimento foi desenvolvido em casa-devegetação, com delineamento experimental de blocos casualizados, fatorial 3 x 5 [doses de $A$. brasilense $(0.0 ; 0.32$; e $0.48 \mathrm{~mL} / 100$ sementes) e níveis de condutividade elétrica da água $(0.3 ; 0.6$; $1.1 ; 1.7$; e $\left.2.3 \mathrm{dS} \mathrm{m}^{-1}\right)$ ], em 4 blocos, totalizando 60 unidades experimentais. Foram avaliados a porcentagem de emergência, índice de velocidade de emergência, altura de planta, diâmetro de colmo, número de folhas, área foliar e massa seca de folhas, colmo, pendão e raízes. Os tratamentos entre salinidade e inoculação não apresentaram efeito sobre a emergência das plântulas. A salinidade afetou significativamente o crescimento; porém, o número de folhas apresentou acréscimos de $12.8 \%$ (V8) e $18.8 \%$ (V10), comparandose a diferença entre a menor e maior salinidade estudada. Quanto à altura de planta, houve incremento de $3,7 \%$ até a salinidade limiar da cultura $\left(1.1 \mathrm{dS} \mathrm{m}^{-1}\right)$. Ocorreu aumento de massa seca das raízes com a aplicação das doses de inoculante em cada nível salino estudado.

PALAVRAS-CHAVE: Zea mays L., Azospirillum brasilense, qualidade da água.

of photosynthesis, respiration and transpiration are directly linked to heat, while the growth, development and translocation of photoassimilates are due to water availability (Fancelli 2015).

Therefore, the water quality becomes extremely important in the maize cultivation, especially in semiarid regions, requiring water use policies, due to its scarcity. In theory, the use of saline water has been studied for some years; however, maize, according to Ayers \& Westcot (1999) and Farooq et al. (2015),

\footnotetext{
${ }^{1}$ Received: Oct. 10, 2020. Accepted: Nov. 25, 2020. Published: Dec. 22, 2020. DOI: 10.1590/1983-40632020v5066102.

${ }^{2}$ Universidade Federal de Campina Grande, Centro de Tecnologia e Recursos Naturais, Campina Grande, PB, Brasil.

Email/ORCID: hallysonoliveira_@hotmail.com/0000-0001-5272-1254,ronaldon453@gmail.com/0000-0002-5086-8532, elka_costa@hotmail.com/0000-0001-7202-6216,robson_felipe88@hotmail.com/0000-0003-4975-6610, 
is considered moderately sensitive to salinity, with a water threshold of $1.1 \mathrm{dS} \mathrm{m}^{-1}$, what hampers its growth, development and production.

In researches related to maize submitted to saline environments, there is a clear reduction in vigor, growth, physiological, biochemical and production variables. However, from these deleterious effects of salinity in this crop, it is necessary to study techniques or application of products, hormones and bacteria that will mitigate these damages.

The use of growth-promoting bacteria can be a way to mitigate the effect of salinity on plants, because they promote several benefits, such as biological nitrogen fixation; increase in the nitrate reductase activity; production of hormones such as auxins, cytokinins, gibberellins and ethylene; and increase in the root system, among others (Hungria 2011).

Among the growth-promoting bacteria species, the Azospirillum brasilense genus stands out, producing phytohormones that stimulate the growth of the root system of several plants, including maize, through indole-acetic acid, gibberellins and cytokinins (Döbereiner \& Day 1976, Tien et al. 1979, Rocha \& Costa 2018).

As a result, a greater root growth due to the inoculation of these bacteria may result in an increase in the absorption of water and nutrients and improvement in the physiological responses of plants, such as chlorophyll content and stomatal conductance, in addition to increasing the proline content in shoots and roots, water content of the apoplast, elasticity of the cell wall, biomass production, plant height and water potential (Barassi et al. 2008).

Therefore, this research aimed to evaluate the effect of $A$. brasilense doses on the emergence and growth of maize submitted to salinity concentrations of the irrigation water.

\section{MATERIAL AND METHODS}

The research was conducted in a greenhouse, at the Universidade Federal de Campina Grande, in Campina Grande, Paraíba state, Brazil ( $7^{\circ} 13^{\prime} 11^{\prime}$ 'S, $35^{\circ} 52^{\prime} 31^{\prime \prime} \mathrm{W}$ and $550 \mathrm{~m}$ of altitude), between December 2019 and May 2020. According to the Köppen climate classification, adapted to Brazil (Alvares et al. 2013), the climate in the place is CSa, that is, semi-humid, with hot and dry summers (from November to March) and autumn and winter rains.
In the experiment, the NS 50 PRO variety of super-early maize was used, presenting high yields with grain quality and high rooting capacity (Nidera Sementes 2020).

The used soil was collected from an area located in Alagoa Nova, Paraíba state, being classified as sandy loam. The pots were filled with a 3 -cm layer of gravel at the bottom, and then with $20 \mathrm{~kg}$ of soil, being arranged in a single row spaced $0.7 \mathrm{~m}$ between pots and $1 \mathrm{~m}$ between plants.

Based on the recommendation by Novais et al. (1991), the soil was fertilized with NPK [33 $\mathrm{g}$ of simple superphosphate $(\mathrm{P})$ in a single application before seeding; $5.8 \mathrm{~g}$ of potassium chloride (K) at 30 days after the emergence; and $4.4 \mathrm{~g}$ of urea divided into three portions of $1.45 \mathrm{~g}$, during the maize vegetative stage]. Sowing was carried out manually, placing 5 seeds per polyethylene pot with a capacity of $20 \mathrm{~L}$, containing a transparent hose of $5 \mathrm{~mm}$ in diameter and connected to its base, for drainage. At 10 days after emergence (DAE), thinning was performed, leaving only one plant per pot, being considered the one with the greatest vegetative vigor. The seeds were inoculated with the A. brasilense strain, in a mixture in the proportion of $16 \mathrm{~mL}$ of the inoculant for 10,000 seeds.

The experiment was designed in randomized blocks, in a $3 \times 5$ bifactorial arrangement [inoculant doses $(0.0,0.32$ and $0.48 \mathrm{~mL})$, that is, control without inoculation, inoculated 2 times and inoculated 3 times with the recommended dose) and electrical conductivity levels of irrigation water $(0.3,0.6,1.1$, 1.7 and $\left.2.3 \mathrm{dS} \mathrm{m}^{-1}\right)$ ], with 4 replications, totaling 60 experimental units.

The irrigation solution was prepared in order to have an equivalent proportion of 7:2:1 for $\mathrm{Na}: \mathrm{Ca}: \mathrm{Mg}$, respectively, from the salts $\mathrm{NaCl}, \mathrm{CaCl}_{2} \cdot 2 \mathrm{H}_{2} \mathrm{O}$ and $\mathrm{MgCl}_{2} \cdot 6 \mathrm{H}_{2} \mathrm{O}$ (Medeiros 1992, Audry \& Suassuna 1995).

For this, in the irrigation water preparation, the relationship between electrical conductivity (EC) and salt concentration $\left(10 * \mathrm{meq} \mathrm{L}^{-1}=1 \mathrm{dS} \mathrm{m}^{-1}\right.$ of EC) was considered, according to Rhoads et al. (1992), based on the water supply. To prepare the water with the proper electrical conductivity, the salts were weighed according to the treatment, adding water until the desired level of electrical conductivity was reached, checking the values with a portable conductivity meter adjusted to the temperature of $25^{\circ} \mathrm{C}$.

The volume of water initially applied to maintain the soil in the field capacity was calculated according 
to the soil moisture retention curve, performed in laboratory. The water consumption was determined by the difference between the applied volume of water and the drained one, estimating the volume of water to be applied in the next irrigation event.

A leaching fraction of $15 \%$ was weekly applied (Ayers \& Westcot 1999), which served to monitor the salinity levels in the root zone of the plants. This monitoring was carried out through an equation proposed by Szabolcs (1989): VI $=(\mathrm{VA}-$ VD)/(1 - LF), in which: VI is the volume of water to be applied in the irrigation process $(\mathrm{mL})$; VA the volume of water applied in the previous irrigation or in the period $(\mathrm{mL})$; VD the volume of water drained in the previous irrigation or in the period $(\mathrm{mL})$; and LF the leaching fraction (0.15).

Before sowing, the soil was kept under field capacity, in order to homogenize the water conditions of each treatment. The plants were irrigated according to the crop's water requirements.

The emergence percentage $[\mathrm{EP}=(\mathrm{N} / \mathrm{A}) \times 100$, where $\mathrm{N}$ is the number of emerged seeds and $\mathrm{A}$ the total number of seeds placed to germinate; Brasil (2009)] and emergence speed index [ESI $=(\mathrm{G} 1 / \mathrm{N} 1)+$ $(\mathrm{G} 2 / \mathrm{N} 2)+\ldots+(\mathrm{Gn} / \mathrm{Nn})$, where G1, G2 and Gn are the number of seeds emerged in the 1st, 2nd and n, up to the last count; Maguire (1962)] were observed daily, until 10 DAE.

The following growth variables were evaluated in three periods, every 15 days, among the vegetative stages V8 (eight developed leaves), V10 (ten developed leaves) and Vt (budding): plant height, stem diameter, number of leaves and leaf area [LA $\left(\mathrm{cm}^{2}\right)=\mathrm{L} \times \mathrm{W} \times 0.75$, where $\mathrm{L}$ is the length of the main rib of the maize leaf $(\mathrm{cm})$ and $\mathrm{W}$ the largest width perpendicular to the main rib of the maize leaf (cm); Tollenaar (1992)]. The leaves, stem, tassel and roots were collected at the end of the crop physiological maturation and packed in paper bags to have their dry mass weighed in the laboratory.

The results of the variables determined during the maize cycle were subjected to analysis of variance (Anava), using the Sisvar statistical software, and the level of significance by analyzing the $\mathrm{F}$ test at $5 \%$ of probability (Ferreira 2011).

\section{RESULTS AND DISCUSSION}

The emergence percentage and emergence speed index were not affected by the salinity, Azospirillum and interaction factors (Table 1). However, the mean emergence percentage value was $92 \%$, indicating an excellent emergence of maize seedlings, which probably denotes that, at this early stage, both the bacterial inoculant application and the increasing salinity levels of the irrigation water did not influence the emergence of the used maize cultivar.

By evaluating the seed quality of four varieties of corn inoculated with A. brasilense, although there was a significant effect of inoculation on the emergence percentage and emergence speed index, Pereira et al. (2015) considered a very small difference, concluding that these results generated negligible effects between the treatments.

For studies concerning maize salinity at the germination/emergence stage, there are divergences in the results found. Conus et al. (2009) did not obtain significant effects on the germination of maize when submitted to differentiated osmotic potentials $\left(\psi_{\mathrm{s}}\right)$, corroborating the results obtained in the present research. However, Barbieri et al. (2014) found decreasing values for germination percentage as the $\psi_{\mathrm{s}}$ became more negative.

During the growth assessments (Table 1), a significant effect of the salinity factor was identified

Table 1. Analysis of variance for plant height (PH), stem diameter (SD), number of leaves (NL) and leaf area (LA) of maize submitted to doses of Azospirillum brasilense associated with levels of water salinity (CEa).

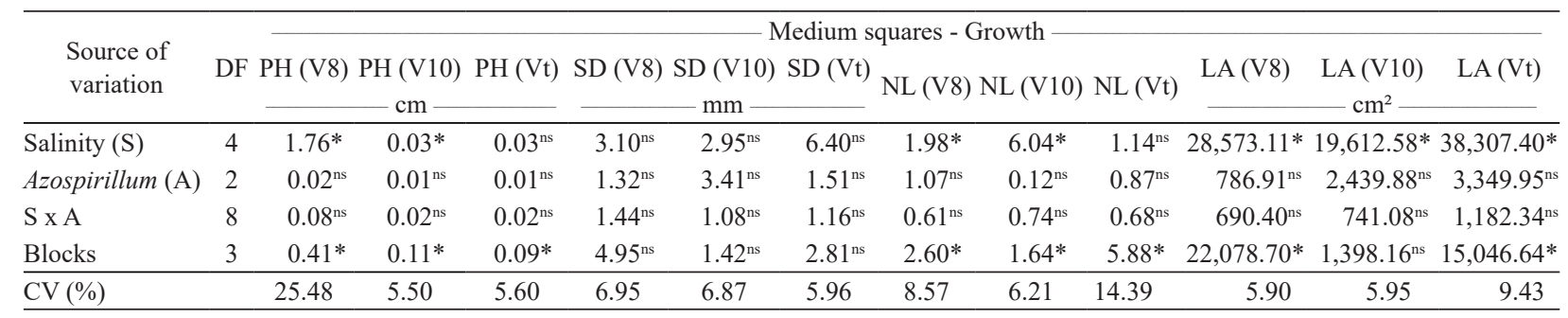

${ }_{\text {ns }}$ Not significant; * significant at $5 \%$ of probability. 
in the first two assessments for plant height (V8 and V10), with significance of $\mathrm{p}<5 \%$ for the Azospirillum factor and for the interaction salinity $\mathrm{x}$ Azospirillum. There was no effect $(\mathrm{p}<5 \%)$ of the analyzed factors on the stem diameter. The number of leaves was significantly affected by the salinity in the evaluations at V8 and V10, while the leaf area suffered the effect of this isolated factor in all evaluations. Statistically, the number of leaves and leaf area were not significant at $5 \%$ of probability for the Azospirillum factor and for the interaction salinity x Azospirillum.

In the first plant height assessment (Figure 1A), there was a linear decrease as the levels of water electrical conductivity increased. In the second one (Figure 1B), a quadratic increase of $3.7 \%$ was observed up to the water electrical conductivity of $1.1 \mathrm{dS} \mathrm{m}^{-1}$, with an effective decrease after this level. Such trend may demonstrate that the A. brasilense doses, when associated with levels of water electrical conductivity below the threshold salinity of maize $\left(1.1 \mathrm{dS} \mathrm{m}^{-1}\right)$, help in its growth after the V8 stage.

There were increases of $12.8 \%$ and $18.8 \%$ in the number of healthy leaves (senescence in less than $50 \%$ of the leaf blade), when related to the difference between the lowest and highest levels of water salinity (Figures 1C and 1D). That may be related to a possible precocious effect on the vegetative development of these plants when subjected to high levels of salts, that is, they reduce their growth in height, however, they develop the insertion of leaves more quickly, and may come to be considered a mechanism of adaptation to salinity.

In addition, the bacterial inoculant may have contributed to maintaining the low senescence of the leaves, even under salinity, because, according to Lambrecht et al. (2000), these bacteria serve as nitrogen supplementation and produce hormones that stimulate the plant growth, retarding the leaf senescence.

Sangoi et al. (2015), studying the leaf senescence and chlorophyll content in maize leaves, in a seed treatment with Azospirillum and nitrogen application, found that the senescence was higher in treatments without inoculation (11.7 leaves), when compared to treatments with inoculation (11.0 leaves).

Although the number of leaves was higher in treatments with a high water electrical conductivity level, the leaf area faced a linear reduction with the increase in salinity (Figures $1 \mathrm{E}, 1 \mathrm{~F}$ and $1 \mathrm{G}$ ), which may be related to the lesser development of the leaf blade, resulting in a leaf with short length and width.

Souza et al. (2014) and Ricardi \& Rosa (2018) studied the effect of salinity on maize development and noticed a decrease in plant height, number of leaves, stem diameter and leaf area due to the increase in salinity levels, not corroborating, partially, the results obtained in this research.

These harmful effects are attributed to several problems. Among them, the most common is the increase in the soil osmotic pressure, making it more negative than that of the plant, thus allowing the water to be absorbed by the roots and affecting its cell division and cell extension (Taiz \& Zeiger 2009). This also justify the fact that the reduction of the leaf area can present a defense of the plant cultivated in a saline environment, aiming to reduce the water loss thought transpiration.

Studies have already demonstrated the deleterious effect of salinity on growth variables of maize plants (Silva et al. 2017, Sousa et al. 2018); however, there have been no studies about the interaction of this abiotic stress with the application of $A$. brasilense as a saline attenuating agent in maize.

Martins et al. (2018), evaluating the interaction between $A$. brasilense inoculation and nitrogen fertilizer doses in maize, observed that, even without the application of nitrogen, that is, plants submitted only to the application of $A$. brasilense (control), there was an increase of $22.4 \%$ in height. That was also verified by Costa et al. (2015) and Kappes et al. (2013), obtaining increases in plant height, on average, of $10 \%$ and $5.84 \%$, respectively.

By observing the isolated factors salinity and Azospirillum, in addition to the salinity x Azospirillum interaction, concerning the leaf, stem, tassel and root dry masses, it was found a significant effect $(\mathrm{p}<5 \%)$ of the increasing levels of salts on leaf dry mass and stem dry mass, in addition to the interaction effect for root dry mass (Table 2).

The leaf dry mass showed a quadratic increase of $30.2 \%$ with the increase in the levels of water electrical conductivity, varying between $37.94 \mathrm{~g}$ $\left(0.3 \mathrm{dS} \mathrm{m}^{-1}\right)$ and $49.50 \mathrm{~g}\left(2.3 \mathrm{dS} \mathrm{m}^{-1}\right)$ (Figure $\left.2 \mathrm{~A}\right)$. The stem dry mass had a linear reduction as the levels of salts in the irrigation water increased (Figure 2B), with average values between the water electrical conductivity of $0.3 \mathrm{dS} \mathrm{m}^{-1}$ and $2.3 \mathrm{dS} \mathrm{m}^{-1}$, ranging from $136.83 \mathrm{~g}$ to $98.09 \mathrm{~g}$, respectively. 

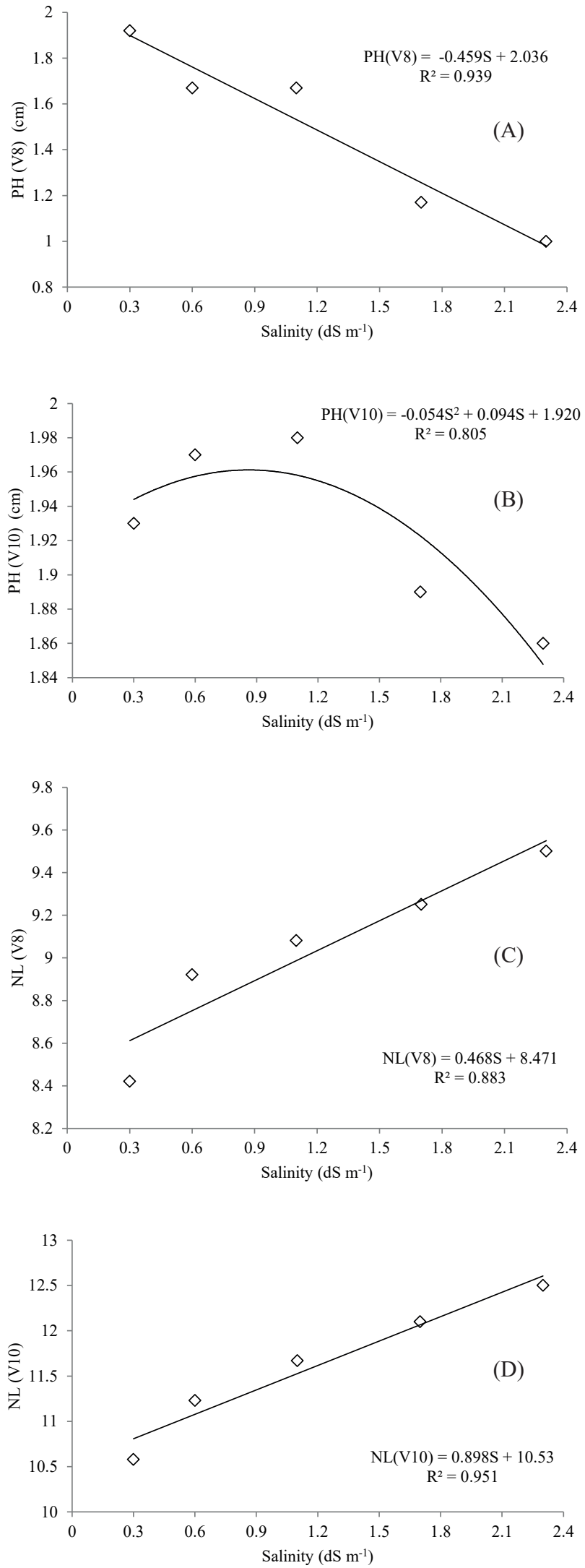

In general, the salinity effect on maize shoot is harmful, reducing the dry biomass of leaves, stem and tassel. However, the usual application of A. brasilense in maize causes the opposite (Braccini et al. 2012, Quadros et al. 2014, Marini et al. 2015). That may justify the increase in the leaf dry mass (Figure 2A), reflecting a possible attenuator effect of these bacteria on the possible damage of salinity in the leaves, since the A. brasilense species is directly linked to the solubilization of nutrients and production of phytohormones related to plant
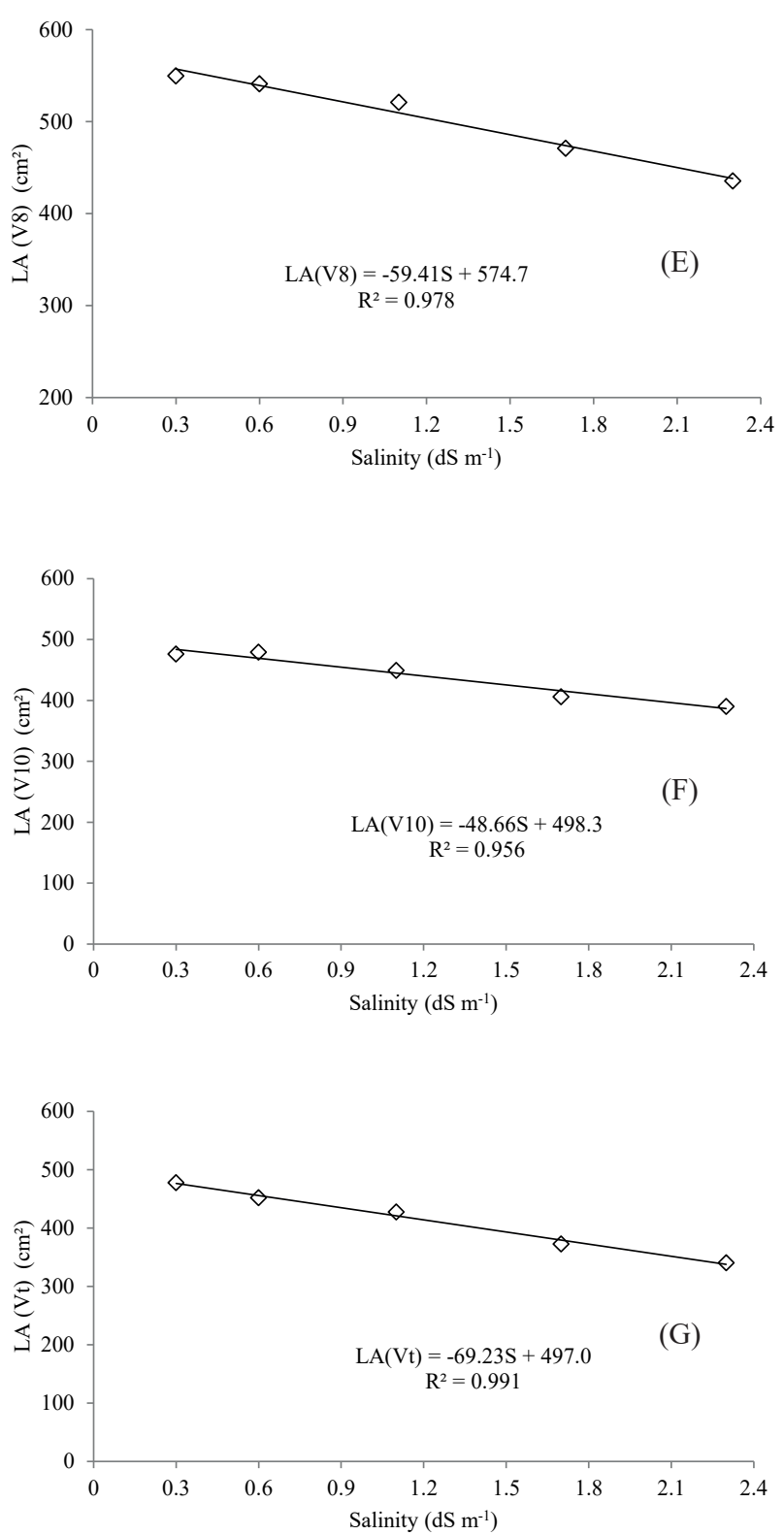

Figure 1. Effect of increasing salinity levels of water irrigation on maize plant height (PH), number of leaves (NL) and leaf area (LA), in growth evaluations at V8, V10 and Vt. 
Table 2. Analysis of variance of the leaf (LDM), stem (SDM), tassel (TDM) and root (RDM) dry mass of maize submitted to doses of Azospirillum brasilense associated with levels of water salinity.

\begin{tabular}{|c|c|c|c|c|c|}
\hline \multirow[b]{2}{*}{ Source of variation } & \multirow[b]{2}{*}{ DF } & \multicolumn{4}{|c|}{ Medium square } \\
\hline & & LDM & SDM & TDM & RDM \\
\hline Salinity (S) & 4 & $333.32 *$ & $3,469.47 *$ & $0.83^{\text {ns }}$ & $28.686 .15^{*}$ \\
\hline Azospirillum (A) & 2 & $51.77^{\mathrm{ns}}$ & $1,802.78^{\text {ns }}$ & $0.10^{\mathrm{ns}}$ & $3,768.21 *$ \\
\hline $\mathrm{S} \times \mathrm{A}$ & 8 & $38.02^{\mathrm{ns}}$ & $590.07^{\mathrm{ns}}$ & $0.58^{\text {ns }}$ & $947.07^{*}$ \\
\hline Blocks & 3 & $21.04^{\mathrm{ns}}$ & $723.45^{\mathrm{ns}}$ & $0.68^{\mathrm{ns}}$ & $124.34^{\mathrm{ns}}$ \\
\hline $\mathrm{CV}(\%)$ & & 12.40 & 27.90 & 20.05 & 18.68 \\
\hline
\end{tabular}

${ }^{\mathrm{ns}}$ Not significant; $*$ significant at $5 \%$ of probability.
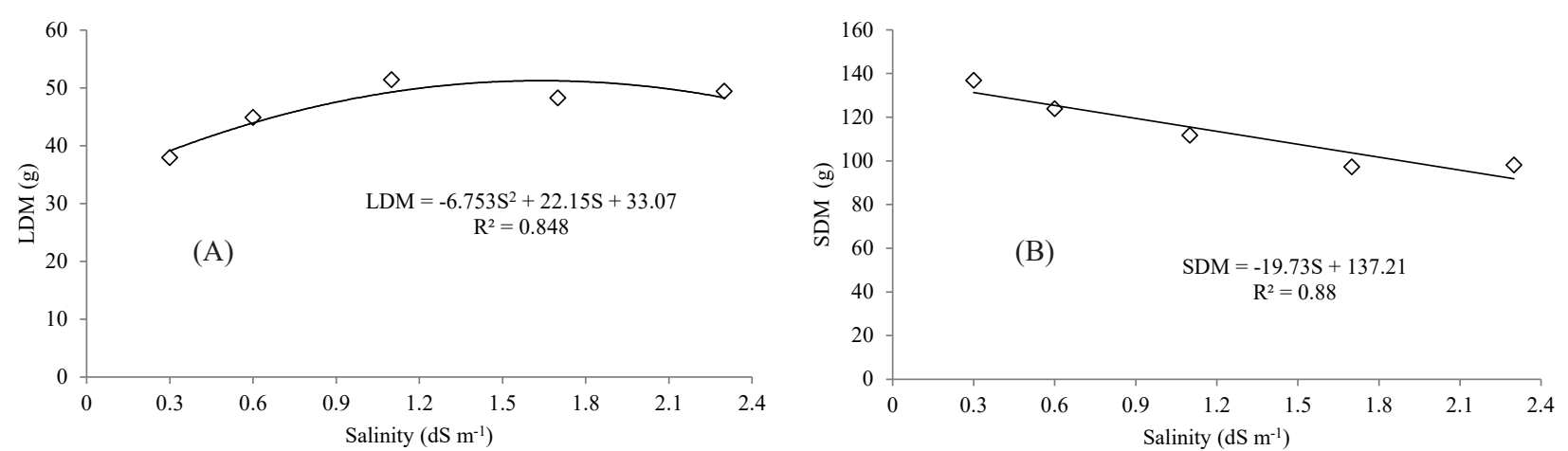

Figure 2. Effect of increasing salinity levels of irrigation water on maize leaf dry mass (LDM) and stem dry mass (SDM).

growth, such as auxins, gibberellins and cytokinins (Picazevicz 2017).

By analyzing the split of inoculant doses at each water electrical conductivity level, it can be seen that increasing doses, mainly $0.48 \mathrm{~mL}$, positively influenced the increase in the root dry mass in all the water electrical conductivity levels $(0.3,0.6,1.1,1.7$ and $2.3 \mathrm{dS} \mathrm{m}^{-1}$ ), showing increases of $30.11 \%, 49.79 \%$, $15.80 \%, 40.92 \%$ and $81.89 \%$, respectively (Figure 3). It probably caused a mitigation of the adverse effects of salinity on the growth of maize plants through a larger root system, thus increasing its contact surface and, consequently, the water and nutrient absorption.

As the root system is the main way of water and nutrients absorption by plants, the results obtained for root dry mass may justify other results found in this research, for example, the increase in plant height up to the salinity of $1.1 \mathrm{dS} \mathrm{m}^{-1}$ (Figure 1B) and the increase in the number of leaves (Figures $1 \mathrm{C}$ and 1D), as well as the increase in leaf dry mass (Figure 2A), demonstrating that, even submitted to saline stress, the plants probably managed to maintain their biochemical and physiological activities inherent to growth, even if in a slow way.
According to Spaepen \& Vanderleyden (2015), auxin is the phytohormone produced by $A$. brasilense that is related to the increase in the plant root system, causing morphological changes such as increased length, branches and root hair.

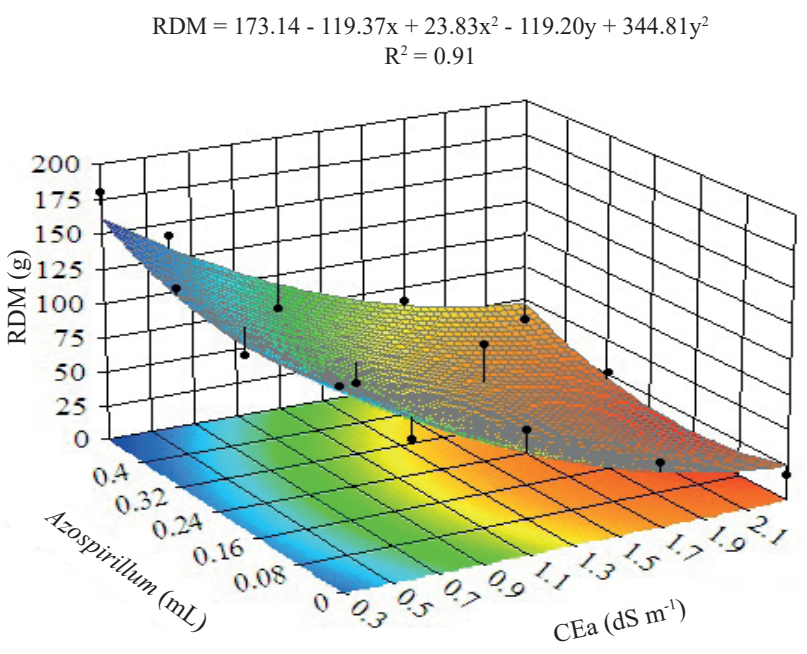

Figure 3. Effect of Azospirillum brasilense doses associated with increasing salinity levels of irrigation water $(\mathrm{CEa})$ on maize root dry mass (RDM). 
Studies prove the effectiveness of $A$. brasilense in increasing the root dry mass. Okon \& Vanderleyden (1997) analyzed the inoculation of Azospirillum on plant growth in the field and concluded that these bacteria provide positive yields in various conditions of climate and soil, and also increase the absorption surface of roots, providing a greater exploration of the soil.

Costa et al. (2015), studying the inoculation efficiency of these bacteria in maize seeds, observed an increase of $123 \%$ for root dry mass, when compared to the control. Domingues Neto et al. (2013), verifying the application of these bacteria via leaf, also obtained an increase for maize root dry mass.

\section{CONCLUSIONS}

1. The studied salinity levels of the irrigation water and Azospirillum brasilense doses do not affect the emergence of maize seedlings;

2. After the V8 stage, the plant height increases up to the salinity of $1.1 \mathrm{dS} \mathrm{m}^{-1}$. In addition, the number of leaves and leaf dry mass increase with major salt concentrations. However, salinity negatively affects the leaf area and stem dry mass;

3. There is an interaction between the levels of electrical conductivity of the irrigation water and the $A$. brasilense doses for root dry mass, with an increase for root dry mass due to the increase of the bacterial inoculant doses;

4. The use of saline water with electrical conductivity up to $1.1 \mathrm{dS} \mathrm{m}^{-1}$ is recommended for maize growth;

5. For the application of $A$. brasilense doses, both the doses of $0.32 \mathrm{~mL}$ and $0.48 \mathrm{~mL}$ are recommended for maize growth.

\section{REFERENCES}

ALVARES, C. A.; STAPE, J. L.; SENTELHAS, P. C.; GONÇALVES, J. L. M.; SPAROVEK, G. Köppen's climate classification map for Brazil. Mateorologische Zeitschrift, v. 22, n. 6, p. 711-728, 2013.

AUDRY, P.; SUASSUNA, J. A. A qualidade da água na irrigação do trópico semiárido: um estudo de caso. In: SEMINÁRIO FRANCO-BRASILEIRO DE PEQUENA IRRIGAÇÃO, 1995, Recife. Anais... Recife: CNPq/ Sudene, 1995. p. 147-153.

AYERS, R. S.; WESTCOT, D. W. A qualidade da água na agricultura. 2. ed. Campina Grande: Ed. UFPB, 1999.
BARASSI, C. A.; SUELDO, R. J.; CREUS, C. M.; CARROZZI, L. E.; CASANOVAS, W. M.; PEREYRA, M. A. Potencialidad de Azospirillum en optimizer el crecimiento vegetal bajo condiciones adversas. In: CASSÁN, F. D.; GARCIA de SALAMONE, I. (ed.). Azospirillum sp.: cell physiology, plant interactions and agronomic research in Argentina. Córdoba: Asociación Argentina de Microbiologia, 2008. p. 49-59.

BARBIERI, A. P. P.; HUTH, C.; ZEN, H. D.; BECHE, M.; HENNING, L. M. M.; LOPES, S. J. Tratamento de sementes de milho sobre o desempenho de plântulas em condições de estresse salino. Revista de Ciências Agrárias, v. 57, n. 3, p. 305-311, 2014.

BRACCINI, A. de L.; DAN, L. G. de M.; PICCININ, G. G.; ALBRECHT, L. P.; BARBOSA, M. C.; ORTIZ, A. H. T. Seed inoculation with Azospirillum brasilense, associated with the use of bioregulators in maize. Revista Caatinga, v. 25, n. 2, p. 58-64, 2012.

BRASIL. Ministério da Agricultura, Pecuária e Abastecimento. Regras para análise de sementes. Brasília, DF: MAPA/ACS, 2009.

CONUS, L. A.; CARDOSO, P. C.; VENTUROSO, L. R.; SCALON, S. P. Q. Germinação de sementes e vigor de plântulas de milho submetidas ao estresse salino induzido por diferentes sais. Revista Brasileira de Sementes, v. 31, n. 4, p. 67-74, 2009.

COSTA, R. R. G. F.; QUIRINO, G. S. F.; NAVES, D. C. F.; SANTOS, C. B.; ROCHA, A. F. S. Efficiency of inoculant with Azospirillum brasilense on the growth and yield of second-harvest maize. Pesquisa Agropecuária Tropical, v. 45, n. 3, p. 304-311, 2015.

DÖBEREINER, J.; DAY, J. M. Associative symbiosis in tropical grasses: characterization of microorganisms and dinitrogen-fixing sites. In: INTERNATIONAL SYMPOSIUM ON NITROGEN FIXATION, 1976, Pullman. Proceedings... Pullman: Washington State University Press, 1976. p. 518-538.

DOMINGUES NETO, F. J.; YOSHIMI, F. K.; GARCIA, R. D.; MIYAMOTO, Y. R.; DOMINGUES, M. C. S. Desenvolvimento e produtividade do milho verde safrinha em resposta à aplicação foliar com Azospirillum brasilense. Enciclopédia Biosfera, v. 9, n. 17, p. 1030-1040, 2013.

FANCELLI, A. L. Cultivo racional e sustentável requer maior conhecimento sobre planta do milho. Visão Agrícola, v. 13, n. 9, p. 20-23, 2015.

FAROOQ, M.; HUSSAIN, M.; WAKEEL, A.; SIDDIQUE, K. H. M. Salt stress in maize: effects, resistance mechanism, and management: a review. Agronomy for Sustainable Development, v. 35, n. 2, p. 461-481, 2015.

FERREIRA, D. F. Sisvar: a computer statistical analysis system. Ciência e Agrotecnologia, v. 35, n. 6, p. 10391042, 2011. 
HUNGRIA, M. Inoculação com Azospirillum brasilense: inovação em rendimento a baixo custo. Londrina: Embrapa Soja, 2011.

KAPPES, C.; ARF, O.; ARF, M. V.; FERREIRA, J. P.; BEM, E. A. D.; PORTUGAL, J. R.; VILELA, R. G. Inoculação de sementes com bactéria diazotrófica e aplicação de nitrogênio em cobertura e foliar em milho. Semina: Ciências Agrárias, v. 34, n. 2, p. 527-538, 2013.

LAMBRECHT, M.; OKON, Y.; BROEK, A. V.; VANDERLEYDEN, J. Indole-3-acetic acid, a reciprocal signalling molecule in bacteria-plant interaction. Trends in Microbiology, v. 8, n. 7, p. 298-300, 2000.

MAGUIRE, J. D. Speed of germination-aid in selection and evaluation for seedling emergence and vigor. Crop Science, v. 2, n. 1, p. 176-177, 1962.

MARINI, D.; GUIMARÃES, V. F.; DARTORA, J.; LANA, M. C.; PINTO JÚNIOR, A. S. Growth and yield of corn hybrids in response to association with Azospirillum brasilense and nitrogen fertilization. Revista Ceres, v. 62, n. 1, p. 117-123, 2015.

MARTINS, T. G.; FREITAS JÚNIOR, S. P.; LUZ, L. N.; MARCO, C. A.; VÁSQUEZ, E. M. F. Inoculation efficiency of Azospirillum brasilense on economising nitrogen fertiliser in landrace popcorn. Revista Ciência Agronômica, v. 49, n. 2, p. 283-290, 2018.

MEDEIROS, J. F. Qualidade de água de irrigação e evolução da salinidade nas propriedades assistidas pelo GAT nos estados de RN, PB e CE. 1992. Dissertação (Mestrado em Engenharia Agrícola) - Universidade Federal da Paraíba, Campina Grande, 1992.

NIDERA SEMENTES. NS 50 RR2, PRO, PRO2. 2020. Disponível em: http://www.niderasementes.com.br/ produto/ns-50-pro--centro.aspx. Acesso em: 07 abr. 2020.

NOVAIS, R. F.; NEVES, J. C. L.; BARROS, N. F. Ensaio em ambiente controlado. In: OLIVEIRA, A. J.; GARRIDO, W. E.; ARAÚJO, J. D.; LOURENÇO, S. Métodos de pesquisa em ambiente controlado. Brasília, DF: Embrapa, 1991. p. 189-198.

OKON, Y.; VANDERLEYDEN, J. Root-associated Azospirillum species can stimulate plants. Applied and Environmental Microbiology, v. 6, n. 7, p. 366-370, 1997.

PEREIRA, L. M.; PEREIRA, E. M.; REVOLTI, L. T. M.; ZINGARETTI, S. M.; MÔRO, G. V. Seed quality, chlorophyll content index and leaf nitrogen levels in maize inoculated with Azospirillum brasilense. Revista Ciência Agronômica, v. 46, n. 3, p. 630-637, 2015.

PICAZEVICZ, A. A. C. Crescimento do milho em resposta a Azospirillum brasilense, Rhizobium tropici, molibdênio e nitrogênio. 2017. Tese (Doutorado em Produção Vegetal) Universidade Federal do Acre, Rio Branco, 2017.
QUADROS, P. D.; ROESCH, L. F. W.; SILVA, P. R. F.; VIEIRA, V. M.; ROEHRS, D. D.; CAMARGO, F. A. O. Desempenho agronômico a campo de híbridos de milho inoculados com Azospirillum. Revista Ceres, v. 61, n. 2, p. 209-218, 2014.

RHOADES, J. D.; KADIAH, A.; MASHALI, A. M. The use of saline waters for crop production. Rome: FAO, 1992.

RICARDI, M.; ROSA, H. A. Desenvolvimento inicial do milho submetido a estresse salino. Cultivando o Saber, ed. especial, p. 174-184, 2018.

ROCHA, A. F. S.; COSTA, R. R. G. F. Azospirillum brasilense e adubação de cobertura com $\mathrm{N}$ : efeitos no desempenho de Pennisetum glaucum (L.) R. BR. Revista Mirante, v. 11, n. 8, p. 157-166, 2018.

SANGOI, L.; SILVA, L. M. M.; MOTA, M. R.; PANISON, F.; SCHMITT, A.; SOUZA, N. M.; GIORDANI, W.; SCHENATTO, D. E. Desempenho agronômico do milho em razão do tratamento de sementes com Azospirillum sp. e da aplicação de doses de nitrogênio mineral. Revista Brasileira de Ciência do Solo, v. 39, n. 1, p. 1141-1150, 2015.

SILVA, F. A.; FERREIRA, A. A.; LIMA, D. C.; MEDEIROS, A. C.; MARACAJA, P. B.; MEDEIROS, A. P. Estresse salino e adubação mineral na composição nutricional da cultura do milho. Revista Brasileira de Gestão Ambiental, v. 11, n. 1, p. 76-83, 2017.

SOUSA, G. G.; RODRIGUES, V. O.; SALES, J. R. S.; CAVALCANTE, F.; SILVA, G. L.; LEITE, K. N. Estresse salino e cobertura vegetal morta na cultura do milho. Revista Brasileira de Agricultura Irrigada, v. 12, n. 7, p. 3078-3089, 2018.

SOUZA, M. W. L.; CUNHA, R. C.; COSTA, P. A. A.; MOURA, I. N. B. M.; BEZERRA, M. F. S.; LIMA, L. A.; PEREIRA, L. A. F.; OLIVEIRA, F. A. Desenvolvimento inicial de milho doce e milho de pipoca sob estresse salino. Agropecuária Científica no Semiárido, v. 10, n. 3, p. $65-72,2014$.

SPAEPEN, S.; VANDERLEYDEN, J. Auxin signaling in Azospirillum brasilense: a proteome analysis. In: BRUIJIN, F. J.; SONS, J. W. Biological nitrogen fixation. Hoboken: New Jersey, 2015. p. 937-940.

SZABOLCS, I. Salt affected soils. Boca Raton: CRC Press, 1989.

TAIZ, L.; ZEIGER, E. Fisiologia vegetal. 4. ed. Porto Alegre: Artmed, 2009.

TIEN, T. M.; GASKINS, M. H.; HUBBELL, D. H. Plant growth substances produced by Azospirillum brasilense and their effect on the growth of pearl millet (Pennisetum americanum L.). Applied and Environmental Microbiology, v. 37, n. 5, p. 1016-1024, 1979.

TOLLENAAR, M. Is low plant density a stress in maize? Maydica, v. 37, n. 2, p. 305-311, 1992. 